\title{
The ceramics of Malpaís of Zacapu, Michoacán, Mexico, during the Early and Middle Postclassic periods (900-1450 AD): Micro-chemical characterization of surface paintings
}

\author{
E. Jadot ${ }^{\mathrm{a}, \mathrm{b}}, \mathrm{N}$. Schiavon ${ }^{\mathrm{c}}, \mathrm{M}$. Manso ${ }^{\mathrm{d}, \mathrm{e}, *}$ \\ a Université Paris 1 Panthéon-Sorbonne, Centre Michelet, 3 rue Michelet, 75006 Paris, France \\ b ArchAm - UMR 8096 CNRS, MAE, 21 Allée de l'Université, 92023 Nanterre, France \\ ${ }^{\text {c } H E R C U L E S ~ L a b o r a t o r y, ~ U n i v e r s i t y ~ o f ~ E ́ v o r a, ~ P a l a ́ c i o ~ d o ~ V i m i o s o, ~ L a r g o ~ M a r q u e ̂ s ~ d e ~ M a r i a l v a ~ 8, ~ 7000-809 ~ E ́ v o r a, ~ P o r t u g a l ~}$ \\ d Laboratório de Instrumentação, Engenharia Biomédica e Física da Radiação (LIBPhys-UNL), Departamento de Física, Faculdade de Ciências e Tecnologias, Universidade Nova de Lisboa, \\ 2829-516 Monte da Caparica, Portugal \\ e Faculdade de Belas-Artes da Universidade de Lisboa, Largo da Academia Nacional de Belas-Artes, 1249-058 Lisboa, Portugal
}

\section{A R T I C L E I N F O}

\section{Article history:}

Received 15 November 2015

Received in revised form 2 March 2016

Accepted 4 March 2016

Available online 8 March 2016

\section{Keywords:}

$\mu$-Raman

BSEM-EDS

$\mu$-XRD

$\mu$-XRF

Tarascan ceramics

\begin{abstract}
A B S T R A C T
Tarascan ceramic sherds from two Postclassical archaeological sites (900-1450 AD) at the Malpaís of Zacapu, Michoacán, Mexico, were investigated by combining Back-Scattered Scanning Electron Microscopy and Energy Dispersive Spectroscopy (BSEM-EDS), $\mu$-X-Ray Diffractometry ( $\mu$-XRD), $\mu$-X-ray Fluorescence Spectroscopy ( $\mu$-XRF) and $\mu$-Raman Spectroscopy. These sherds are famous for their forms and decorations although the composition of its raw materials remains so far unknown and focused only on the composition of the ceramic paste. For the purpose of surface decoration characterization, the pigments used in slips and paintings were identified as hematite, magnetite, amorphous carbon, graphite and lignite. Furthermore chemical and molecular structure determination allowed the identification of technological aspects such as the firing temperatures and atmospheres used in ceramics production.
\end{abstract}

(c) 2016 Elsevier B.V. All rights reserved.

\section{Introduction}

The Tarascan state in Pre-Columbian Mexico, roughly covered the geographic area of the present-day Mexican state of Michoacán (Fig. 1). At the time of the Spanish conquest (1521 AD), it was the second-largest state in Mesoamerica. In the lake Zacapu basin, two archaeological urban sites situated on the volcanic complex of the Malpaís of Zacapu, El Palacio (Mich.23) and El Malpaís Prieto (Mich.31), were excavated within the framework of the Uacúsecha project (dir. G. Pereira, CNRS-Centre National de La Recherche Scientifique). The investigations in a ceremonial area (near a pyramid and a ball-court) in Mich.23, and in domestic structures, funeral area and ceremonial zone (near a pyramid and an altar) in Mich.31, allowed the discovery of numerous pottery sherds of the Postclassic period belonging to the Palacio phase (900-1200 AD) and the Milpillas phase (1200-1450 AD).

These two phases represented a long period of socio-cultural changes which led to the emergence of the centralized Tarascan state,

\footnotetext{
* Corresponding author at: Laboratório de Instrumentação, Engenharia Biomédica e Física da Radiação (LIBPhys-UNL), Departamento de Física, Faculdade de Ciências e Tecnologias, Universidade Nova de Lisboa, 2829-516 Monte da Caparica, Portugal.

E-mail address: marta974@gmail.com (M. Manso).
}

in the middle of the 14th century. Pottery decorations in the two phases are distinct: during the Palacio phase, the majority of the adorned ceramics has plastic decoration; whereas during the Milpillas phase the decorated ceramics show polychrome motives painted in white and red, often associated with a negative decoration, which appears greyish-black [1]. Although Tarascan ceramics are famous for their forms and decorations, the composition of the raw materials remains so far unknown with the few studies available being focused only on the composition of the ceramic paste [2,3].

Studies on surface coatings (slips and paintings) in Mexican ceramics have been mainly concentrated on Maya and Aztec artefacts. Scanning electron microscopy with energy dispersive spectroscopy (SEM-EDS) and X-ray diffraction (XRD) studies have confirmed the use of hematite $\left(\mathrm{Fe}_{2} \mathrm{O}_{3}\right)$, pyrolusite $\left(\mathrm{MnO}_{2}\right)$, maghemite $\left(\gamma-\mathrm{Fe}_{2} \mathrm{O}_{3}\right)$, and calcite $\left(\mathrm{CaCO}_{3}\right)$ respectively used as red, black, brown and cream pigments in Mayan potsherds from 300-1400 AD found at the archaeological site of Lagartero (Chiapas, Mexico). The main mineral components of the orange pigment were identified as hematite and calcite, whereas those of the grey pigment were calcite and pyrolusite [4]. Previous studies by photoacoustic spectroscopy in Aztec ceramics from 1325 to $1521 \mathrm{AD}$ revealed an absorption peak around $530 \mathrm{~nm}$ characteristic of earth sienna pigment $\left(\mathrm{Fe}_{2} \mathrm{O}_{3} \cdot\left(\mathrm{n} \mathrm{H}_{2} \mathrm{O}\right)+\mathrm{MnO}_{2} \cdot\left(\mathrm{n} \mathrm{H}_{2} \mathrm{O}\right)+\right.$ $\mathrm{Al}_{2} \mathrm{O}_{3}$ ). This study was carried out in combination with EDS technique 

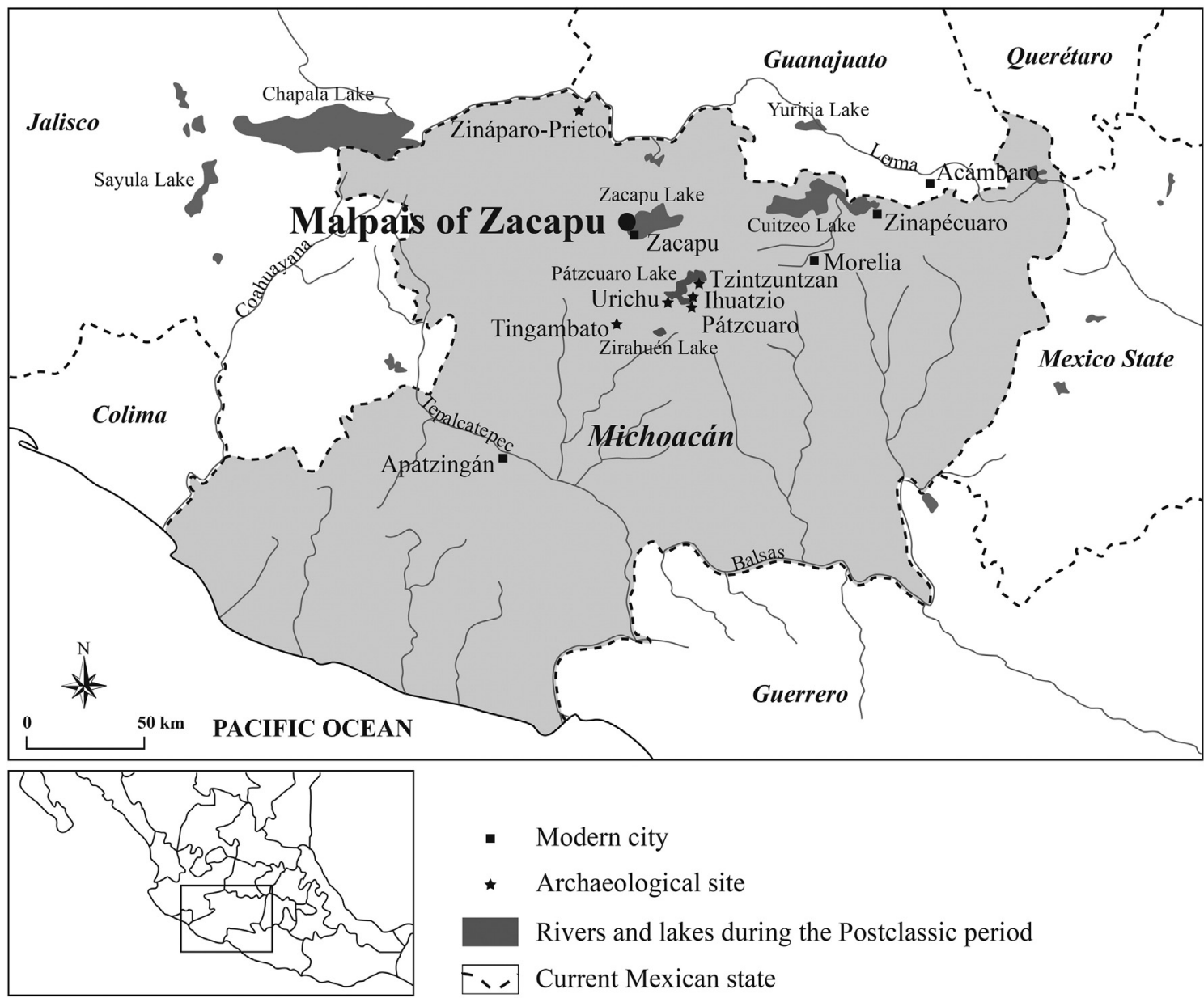

- Modern city

* Archaeological site

Rivers and lakes during the Postclassic period

F. Current Mexican state

Fig. 1. Localisation of the Malpaís of Zacapu, at Michoacán state, Mexico.

that confirmed the presence of iron in the pigment under analysis [5]. Other analytical studies were carried out on Maya ceramics from Guatemala and Honduras neighbouring countries, but none has been conducted on Tarascan ceramics [6,7].

The technology involved in the application of pigments and paintings in archaeological pottery is one of the most interesting aspects of ancient ceramic processing. The use of elemental and molecular structure analytical techniques on archaeological pottery research can provide information about the chemical composition of pigments, paintings and clays, as well as on the technological aspects (firing temperature and redox state of the firing atmosphere), and can define the nature and the provenance of the raw materials used in its production [8].

The general aim of the current study is to extend scientific research on the technology of production of ceramics from Michoacán contributing with the identification of the pigments and firing parameters used in their decoration. We focus our analysis on two main purposes. The first concerns the composition of the paintings and slips, and the firing temperature of the ceramics from the Milpillas phase. Another technical question arises about a black slip from the Palacio phase: it is characterized by a particularly brilliant, almost metallic lustre, resembling the socalled Plumbate surface appearance, originally known in the Maya material culture in the region of Soconusco, in the Pacific slope of southwest Guatemala [9-11]. Instrumental Neutron Activation Analysis proved that it may represent in fact a locally produced imitation of the Maya Plumbate type (H. Neff and M.D. Glascock, personal communication, February 10, 2015). In order to better understand the transfer of technological know-how in pottery manufacturing between these two cultural areas it is fundamental to determine whether the potters could perfectly mimic the original Maya ceramics or if they had to adapt their "recipe" for the local production and the consumption in Zacapu. The second main question concerns the negative technique: how was it made? According to the commonly accepted hypothesis, it would involve, after a first firing, a surface application of a thin layer of clay of the parts of the motif not to become blackened. A second firing of the pottery would then be carried out in order to obtain a carbon smudging of the unprotected areas [2]. This technique is being currently used in pottery workshops of Michoacán using a mixture of clay, water and beeswax. To achieve these aims, $\mu$-X-ray fluorescence ( $\mu$-XRF), BSEM-EDS, $\mu$-XRD and $\mu$-Raman techniques were used. The investigation of organic and inorganic pigments is the dominant issue in the ceramic analysis using Raman spectroscopy. This technique allows the identification of crystalline and amorphous compounds, and the discrimination of the mineral phases without the interference of matrix signal [6,12-14]. Nevertheless the fluorescence effect in Raman spectroscopy may hamper the identification of the pigments characteristic bands and in these cases XRD could represent a good complementary tool although limited to the identification of crystalline compounds. Xray fluorescence technique is a common technique used in the determination of pigments elemental composition and trace elements that can provide relevant information on the provenance of raw pottery materials $[15,16]$. SEM-EDS provides morphological characterization and elemental distribution maps of the decorated surfaces. The nondestructive high resolution and sensibility in the identification of trace elements and organic and inorganic compounds strongly recommend the application of these techniques in the archaeological field. 


\section{Materials and methods}

\subsection{Materials}

Selected sherds for analysis are shown in Fig. 2 while the whole set is described in Table 1. Concerning the study of the composition of the paintings and slips and the firing temperature, seven sherds $(1,2,5,9$, 10 and 7,8 ) plus an imported one (4) were selected. The selected sherds are well preserved and representative of the range of decorations and colours (Malpaís Negative on Red Polished and Malpaís Negative on Polychrome Polished types) used during the Milpillas phase to analyse the white and red colours, and 2 undecorated sherds to study the slips (Milpillas Polished type). One extra sherd of the same phase was also analysed in order to verify if the pigments are the same or not as it represented a fragment of an imported ceramic (Toro Red and Orange Polychrome type). Concerning the study of the negative technique, four of the polychrome sherds were analysed $(1,2,5,10)$. Finally, one sherd of the local Plumbate was selected as well as one fragment of a jar discovered in the same context and which presented a brilliant black deposit that could have been used to prepare the slip ( 3 and 6).

\subsection{Methods}

Analyses were carried out directly on ceramics surfaces combining $\mu$-XRF, BSEM-EDS, $\mu$-XRD and $\mu$-Raman techniques.

\subsection{1. $\mu$-X-ray fluorescence analysis}

Brukers M4 Tornado $\mu$-XRF spectrometer was used. The excitation of fluorescence radiation is performed by a Rh side window X-ray tube with a polycapillary lens offering a spot size down to $25 \mu \mathrm{m}$ combined with high excitation intensity. Detection of fluorescence radiation was performed by an energy-dispersive silicon drift detector with $30 \mathrm{~mm}^{2}$ sensitive area and energy resolution of $142 \mathrm{eV}$ for $\mathrm{Mn}-\mathrm{K} \alpha$. The X-ray generator was operated at $50 \mathrm{kV}$ and $300 \mu \mathrm{A}$. Analyses were carried

Palacio phase (900-1200 AD)

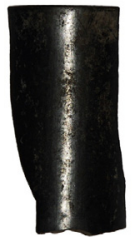

3
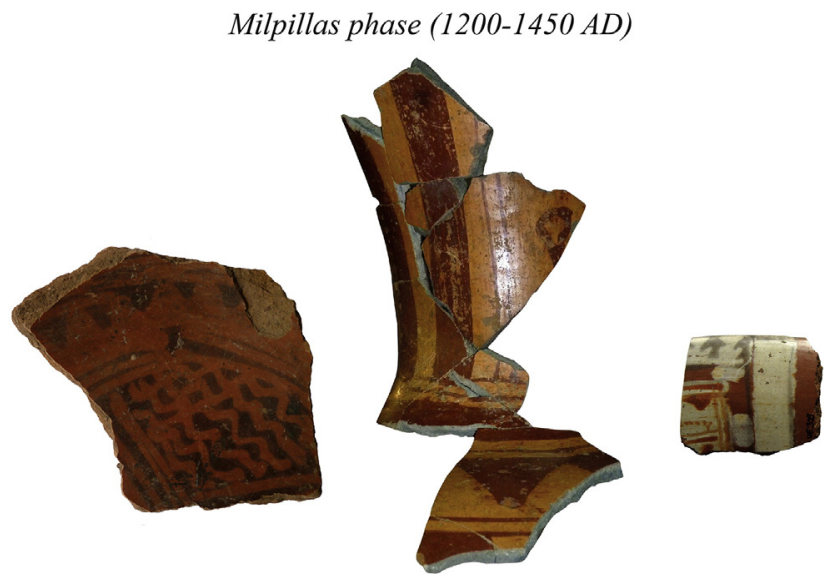

4

Fig. 2. Representative Tarascan ceramic sherds under study. out under 20 mbar vacuum conditions. Spectra acquisition and evaluation were carried out using Esprit software from Bruker.

\subsubsection{Back-scattered scanning electron microscopy with energy dispersive spectroscopy}

BSEM-EDS using a Hitachi S-3700 N interfaced with a Quanta EDS microanalysis system. The Quanta system was equipped with a Bruker AXS XFlash $®$ Silicon Drift Detector (129 eV Spectral Resolution at FWHM/Mn K $\alpha$ ). Standardless PB/ZAF quantitative elemental analysis was performed using the Bruker ESPRIT software. The operating conditions for EDS analysis were as follows: BSEM mode (BSEM), $20 \mathrm{kV}$ accelerating voltage, $10 \mathrm{~mm}$ working distance, $120 \mu \mathrm{A}$ emission current. The detection limits for major elements ( $>\mathrm{Na}$ ) were in the order of $0.1 \mathrm{wt} . \%$.

\subsection{3. $\mu$-X-ray diffraction analysis}

$\mu$-XRD was used to identify crystalline phases. A Bruker AXS D8 Discovery XRD with the Da Vinci design with a $\mathrm{Cu} K \alpha$ source operating at $40 \mathrm{kV}$ and $40 \mathrm{~mA}$ and a lynxeye 1-dimensional detector was used. Scans were run from 3 to $75^{\circ} 2 \theta$.

\subsection{4. $\mu$-Raman analysis}

$\mu$-Raman analyses were undertaken directly on the ceramics surface using a Horiba-Jobin Yvon XploRA confocal spectrometer, operating at wavelength of $785 \mathrm{~nm}$, with maximum incident power of $0.2 \mathrm{~mW}$ to avoid structural modification due to overheating. Using a $100 \times-$ magnification objective with a pinhole of $300 \mu \mathrm{m}$ and an entrance slit of $100 \mu \mathrm{m}$, the scattered light collected by the objective was dispersed onto the air-cooled CCD array of an Andor iDus detector by a 1200 lines/mm grating. Raman microscopy was performed in a range of $100-1800 \mathrm{~cm}^{-1}$. Spectra deconvolution was performed using LabSpec (V5.78). The identification of pigments was made with Spectral $\mathrm{ID}^{\mathrm{TM}}$. Spectra obtained from ceramic samples may present small shifts to the wavenumber and/or larger widths of the bands because of the firing process, which causes a partial loss of crystallinity and mineralogical transformations.

\section{Discussion and results}

\subsection{Palacio phase (900-1200 AD)}

In sherds 3 and $6 \mu$-Raman spectroscopy revealed the presence of two broad bands at 1320 and $1570 \mathrm{~cm}^{-1}$ and at 1338 and $1597 \mathrm{~cm}^{-1}$ respectively (Fig. 3). Carbon characteristic bands are at 1320 and $1600 \mathrm{~cm}^{-1}$. The band at $1320 \mathrm{~cm}^{-1}$ has been shown to broaden and shift to higher wavenumbers as the material becomes less crystalline, and in highly disordered carbon the band at $1600 \mathrm{~cm}^{-1}$ can disappear completely. The very broad nature of the bands recorded on this sample indicates the presence of amorphous carbon [17]. The lack of the phosphate Raman band at $961 \mathrm{~cm}^{-1}$ [18] and of a phosphorus peak in the EDS spectra, indicates that the carbon used is derived originally from charred plant material instead of charred bone. In sherd 3 the characteristic band of graphite at $1580 \mathrm{~cm}^{-1}$ was also identified accompanied of the $1323 \mathrm{~cm}^{-1}$ band (Fig. 3). The presence of the second band is an indication of a less crystalline carbonaceous material since highly crystalline graphite has only one band at $1600 \mathrm{~cm}^{-1}$. This mineral is certainly responsible for the particularly brilliant appearance, almost metallic of the black slip in sherd 3, characteristic of the Plumbate type ceramics, originally known in the Maya area [9-11]. In this area, this slip is composed by iron and alumina [10]. $\mu$-XRD investigation of the surface slip of sherds 3 and 6 confirmed the presence of poorly crystallized graphite together with quartz and feldspars of albitic composition.

\subsection{Milpillas phase (1200-1450 AD)}

Red pigments were found on samples number $1,2,4,5,9,10$. The red decorated areas were identified as hematite $\left(\mathrm{Fe}_{2} \mathrm{O}_{3}\right)$ from the distinct 
Table 1

Sample description.

\begin{tabular}{|c|c|c|c|c|c|}
\hline Sherd & Phase & Site (context) & Form & Ceramic type & Colours \\
\hline 1 & Milpillas & $\begin{array}{l}\text { El Malpaís Prieto } \\
\text { (elite house) }\end{array}$ & Tripod bowl & Malpaís negative on red polished & $\begin{array}{l}\text { Red slip } \\
\text { Greyish-black negative }\end{array}$ \\
\hline $2 a / b$ & Milpillas & $\begin{array}{l}\text { El Malpaís Prieto } \\
\text { (elite funeral) }\end{array}$ & Jar & Malpaís negative on polychrome polished & $\begin{array}{l}\text { Red painting } \\
\text { White painting } \\
\text { Greyish-black negative }\end{array}$ \\
\hline 3 & Palacio & $\begin{array}{l}\text { El Palacio } \\
\text { (ceremonial area) }\end{array}$ & Miniature jar? & Plumbate & Lustrous black slip \\
\hline 4 & Milpillas & $\begin{array}{l}\text { El Malpaís Prieto } \\
\text { (elite funeral) }\end{array}$ & Bottle with handles & Toro red and orange polychrome & $\begin{array}{l}\text { Red painting } \\
\text { Orange slip }\end{array}$ \\
\hline 5 & Milpillas & $\begin{array}{l}\text { El Malpaís Prieto } \\
\text { (elite funeral) }\end{array}$ & Tripod bowl & Malpaís negative on polychrome polished & $\begin{array}{l}\text { Red painting } \\
\text { Light red painting } \\
\text { White painting } \\
\text { Greyish-black negative }\end{array}$ \\
\hline 6 & Palacio & $\begin{array}{l}\text { El Palacio } \\
\text { (ceremonial area) }\end{array}$ & Jar & Unknown & Lustrous black deposit \\
\hline 7 & Milpillas & $\begin{array}{l}\text { El Palacio } \\
\text { (ceremonial area) }\end{array}$ & Bowl & Milpillas polished & $\begin{array}{l}\text { Red slip } \\
\text { Black slip }\end{array}$ \\
\hline 8 & Milpillas & $\begin{array}{l}\text { El Malpaís Prieto } \\
\text { (common house) }\end{array}$ & Bowl & Milpillas polished & $\begin{array}{l}\text { Brown-red slip } \\
\text { Black slip }\end{array}$ \\
\hline 9 & Milpillas & $\begin{array}{l}\text { El Malpaís Prieto } \\
\text { (elite funeral) }\end{array}$ & Bowl & Unknown & $\begin{array}{l}\text { Red painting } \\
\text { White painting }\end{array}$ \\
\hline 10 & Milpillas & $\begin{array}{l}\text { El Malpaís Prieto } \\
\text { (elite funeral) }\end{array}$ & Tripod bowl & Malpaís negative on red polished & $\begin{array}{l}\text { Red slip } \\
\text { Greyish-black negative }\end{array}$ \\
\hline
\end{tabular}

Raman bands at 225, 290, 405, 500, $610 \mathrm{~cm}^{-1}$ [19]. $\mu$-Raman analyses of individual dark red particles in the red matrix show strong bands of hematite. Thin coatings of paint matrix give weak spectra and are identified from the major bands at 225, 290 and $405 \mathrm{~cm}^{-1}$ only.

In the hematite spectra of samples $1,2 \mathrm{~b}, 5$ and 10 a small band at $660 \mathrm{~cm}^{-1}$ is clearly visible in Fig. 4 and can be assigned to the strongest band of magnetite $\left(\mathrm{FeO} \cdot \mathrm{Fe}_{3} \mathrm{O}_{3}\right)$ [20].

According to Gosselain, ceramics fired in open fires or basic pit kilns achieved maximum temperatures of $850-900{ }^{\circ} \mathrm{C}$ and oxidizing conditions [21]. At or below these temperatures most iron oxides are converted to hematite, thus creating the red colour seen on the ceramic samples. Temperatures exceeding $1000{ }^{\circ} \mathrm{C}$ are required to convert hematite back to magnetite $[22,20]$. Even under controlled conditions, temperatures would not have exceeded $950{ }^{\circ} \mathrm{C}$ and would not be high enough to convert hematite into magnetite. The magnetite particles still remaining in the red paint of samples 1, 2b, 5 and 10 must hence be part of the original paint mixture.

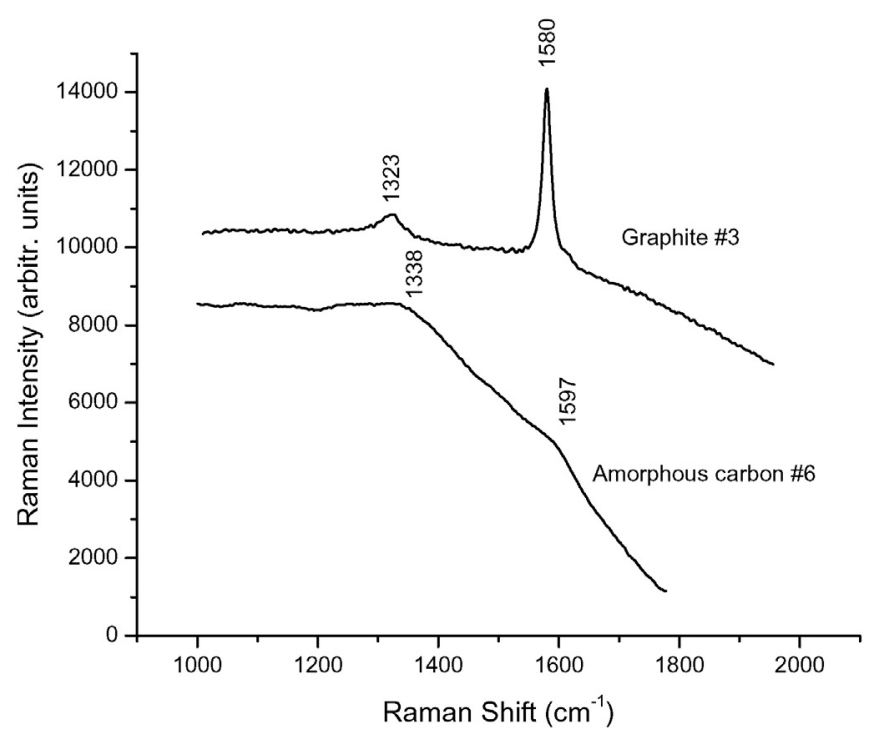

Fig. 3. Raman spectra obtained from pottery sherds number 3 and 6 . Amorphous carbon was identified in both sherds. Graphite was found in Plumbate type jar number 3.
In the imported sherd 4, XRF spectra has shown the presence of iron and bromine peaks in red painting and orange slip areas respectively (Fig. 5). Bromine presence has been recently detected in archaeological materials such as Roman glass [23]. In natural systems, bromine is usually bonded to alkaline metals such as calcium in salts and is abundant (still as a trace element) in modern seawater, where it can reach concentrations up to $70 \mu \mathrm{g} / \mathrm{g}$ [23]. $\mu$-XRD results confirms the association of $\mathrm{Br}$ as detected by $\mu$-XRF with crystalline calcite in sherd 4 . It is interesting to note that with SEM investigation we could find abundant well preserved remains of marine microfossils (foraminifera) in the same sample (Fig. 6). Elemental EDS mapping of red and orange areas in the surface slip of sample 4 also confirmed Fe-enrichment in the red bands.

In sherd 5 hematite was found in both red and light red paintings.

Raman spectra obtained in the monochrome sherd 7 revealed the presence of amorphous carbon on the black slip.

In the case of the negative and polychrome decoration, the question of a preparatory drawing was laid because of the complexity of the technique. The sherds were examined under grazing white light to look for variations in the microtopography, then under infrared light

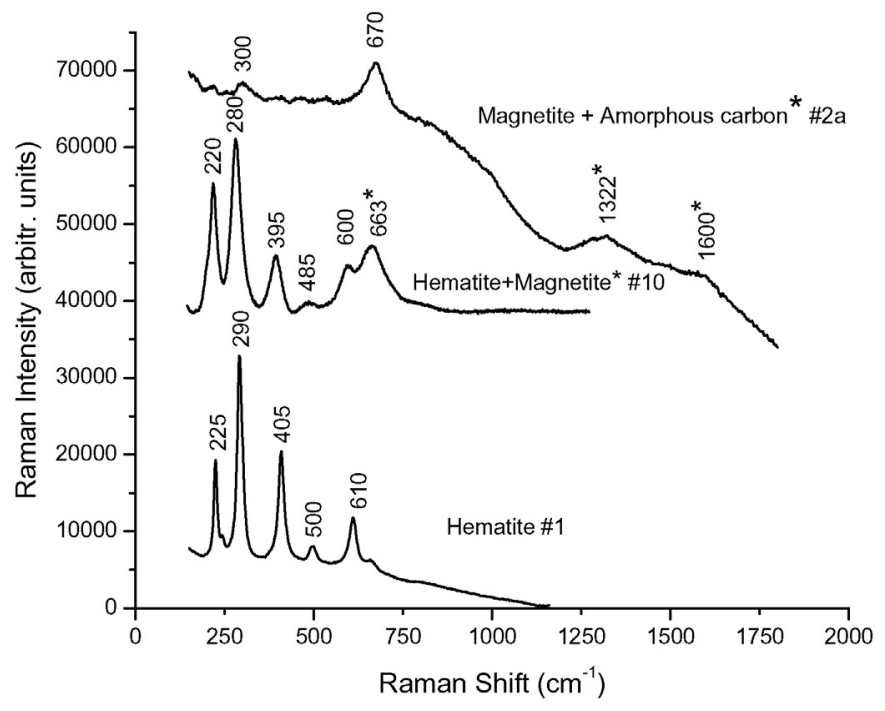

Fig. 4. Raman spectra obtained from pottery sherds number 1, 2a and 10. 
a)
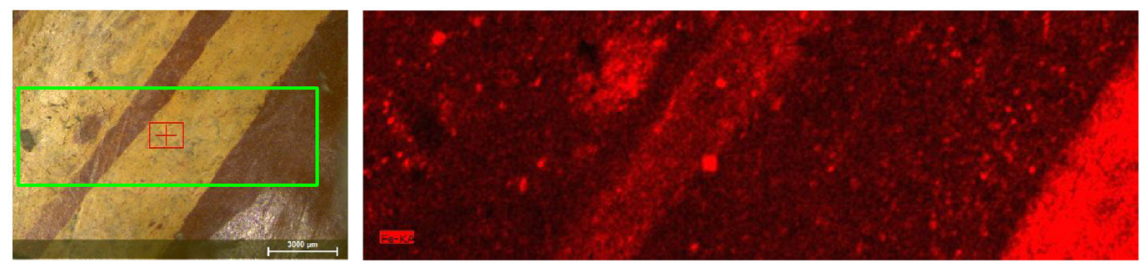

b)

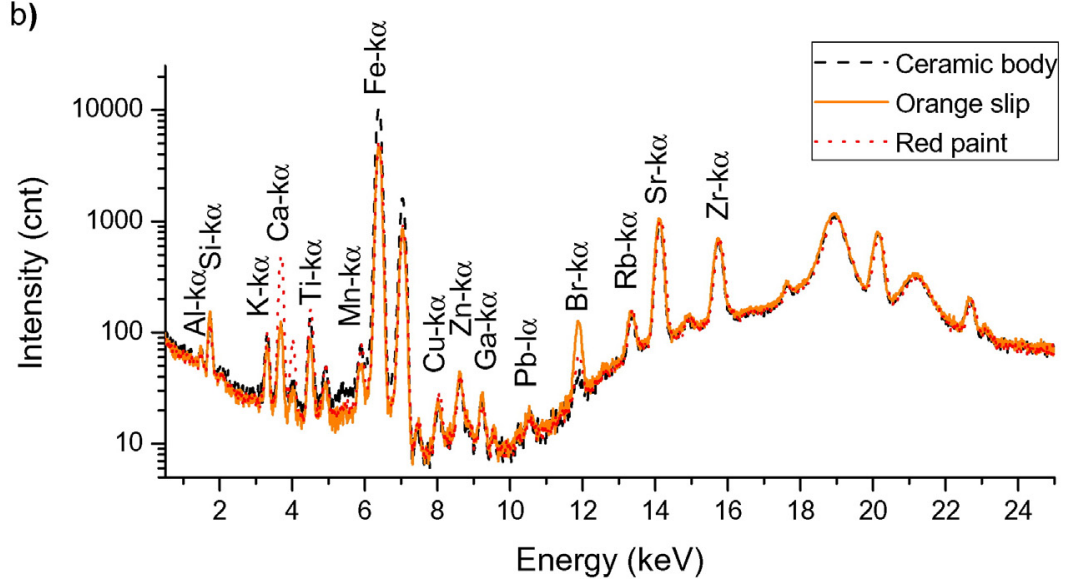

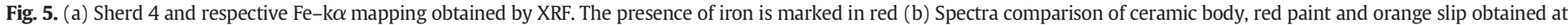
sherd 4 by XRF.

(940 nm) but no evidence of underlying drawings in decorations could be observed.

Concerning the greyish negative decoration characterization, lignite was detected by $\mu$-XRD in sample 1 (Fig. 7) while amorphous carbon was identified by $\mu$-Raman in samples 2 and 10 . Magnetite large broad Raman band at $670 \mathrm{~cm}^{-1}$ [24] was also detected on sherd $2 \mathrm{~b}$.

Furthermore, individual mineral grains of $\mathrm{TiO}_{2}$ in the form of anatase on samples 1, 2, 4, 5 and 9, and less frequently in the form of rutile in sample 5 and quartz $\left(\mathrm{SiO}_{2}\right)$ on samples 2 and 4 appeared to derive from the ceramic paste underlying the pigment layers (Fig. 8). The presence of anatase was confirmed by $\mu$-XRD in samples $1,2 \mathrm{a}$ and 9 . At low temperature, anatase is the most common polymorph of titanium dioxide, stable in $600-900{ }^{\circ} \mathrm{C}$ range, whereas above this temperature threshold anatase converts into rutile, depending on grain size, atmosphere and nature and amount of impurities [25]. Therefore, the presence of anatase may indicate a firing temperature lower than $900{ }^{\circ} \mathrm{C}$. The finding of rutile could suggest that the firing of sherd 5

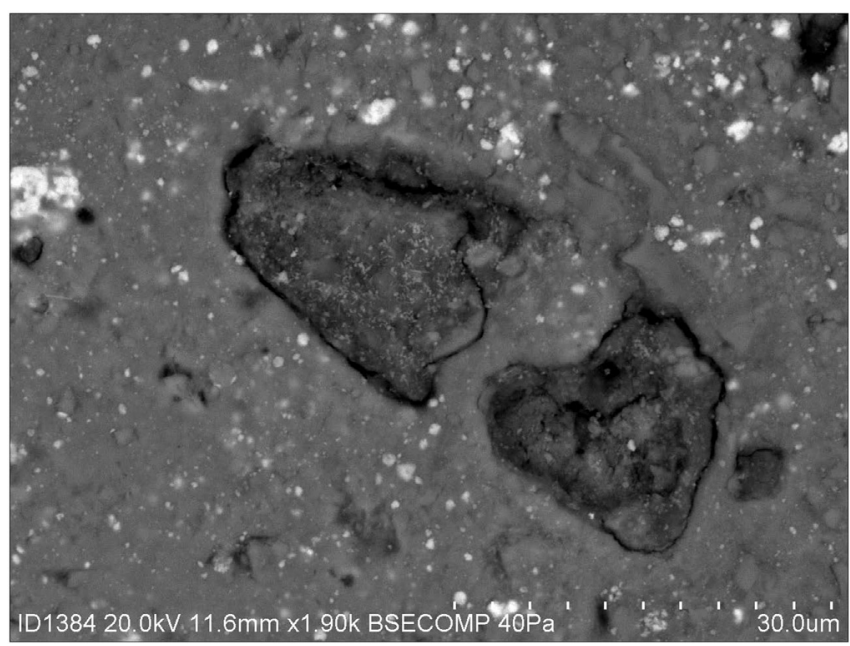

Fig. 6. BSEM image of ceramic paste with well preserved relics of Foraminifera marine microfossils obtained from sherd 4 . may have been carried out at a higher temperature close to the anatase/rutile transition temperature.

Samples of the Milpillas phase show strong peaks of well-crystallized cristobalite, which is a high temperature quartz polymorph. In ceramic manufacturing, conversion of quartz to cristobalite is indicative of firing temperatures exceeding $1100{ }^{\circ} \mathrm{C}$ for long periods of time in the kiln. This would not be compatible with the simultaneous detection of calcite and of well preserved remains of calcitic microfossils in the ceramic paste of many sherds under study. Cristobalite minerals, though, are common in sediments and soils derived from volcanic rocks which are common in the geology of the investigated region. It is therefore likely that the detected cristobalite represents a detrital component of the pottery rather than a product of firing processes bearing in mind also that firing temperature exceeding $1000{ }^{\circ} \mathrm{C}$ were not typical of pre-hispanic pottery technology in central America.

Results obtained by $\mu$-Raman and $\mu$-XRD techniques are summarized on Table 2.

\section{Conclusions}

This study is the first one investigating the colouring materials of the ceramics from Michoacán. The combined analytical approach using atomic spectrometry ( $\mu$-XRF) with electron microscopy + EDS, $\mu$-XRD and $\mu$-Raman spectroscopy brings valuable information at various levels.

For the Palacio phase (900-1200 AD), $\mu$-Raman spectroscopic analysis indicates the use of graphite to give the lustrous aspect to the slip of the local version of Plumbate ceramic (sherd 3). The amorphous carbon also found in this sherd was certainly originated in the smudging at the end of the firing process. The other jar (sherd 6) contains no graphite, only amorphous carbon, so it cannot be associated to the production of this type of decoration. Hitherto, it is not possible to determine if there was a technical transfer from the Maya region of Soconusco to Michoacán, or it represents a simple imitation of products from commercial trade involving the two regions. In both cases, we need to consider that contact could be established in stages, for example via the Toltec people inhabiting central highlands.

For the Milpillas phase (1200-1450 AD), the combined $\mu$-XRF, SEMEDS, $\mu$-XRD and $\mu$-Raman analysis indicate the use of amorphous 


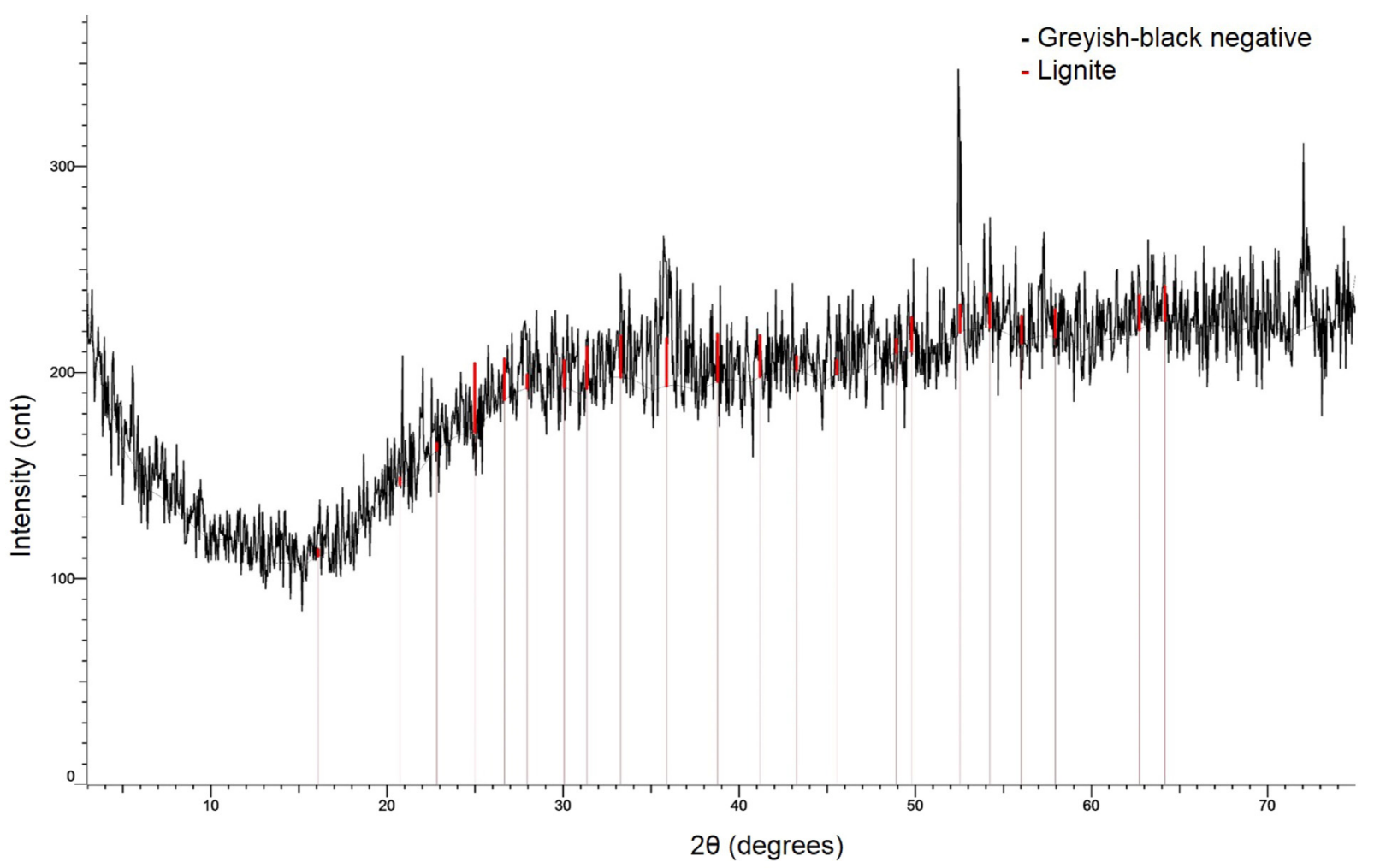

Fig. 7. XRD Pattern from greyish-black negative showing lignite obtained in sherd 1.

carbon, hematite and magnetite based pigments. Back-scattered Electron Microscopy with EDS mapping revealed how the pigments are not evenly distributed within the painted slip but occur in grains and patches.

All the red colours are due to a hematite-based pigment. Thus, the light red painting appears to be obtained from the same preparation as the one used for red paintings and slips but it is certainly diluted to obtain a more fluid texture, giving it a lighter and more transparent aspect. Nevertheless the frequent presence of the Raman band of magnetite in the hematite spectra of the red paint suggests that magnetite was used as raw material and that firing was carried out at low temperatures $\left(600-1000{ }^{\circ} \mathrm{C}\right)$ and oxidizing conditions. The presence

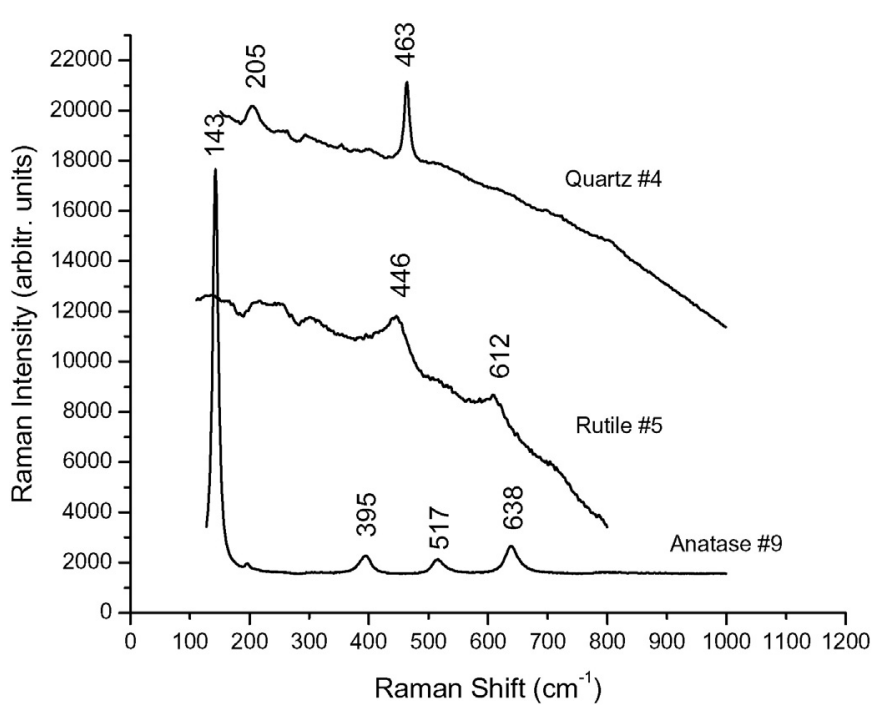

Fig. 8. Raman spectra obtained from pottery sherds 4,5 and 9 . of titanium dioxide in the form of anatase again indicates a firing temperature below $900{ }^{\circ} \mathrm{C}$

The presence of carbon in the greyish black negative decorations and black slip suggests a second firing under a reducing atmosphere, which did not last long enough to transform the hematite in magnetite within the ceramics paste. Negative decoration was obtained through smudging. The same technique was also used in the production of the monochrome ceramics (sherds 7 and 8).

The imported pottery sample (sherd 4 ) (foreign origin confirmed by petrographic analyses) revealed the presence of bromine in the orange slip. This result could support a hypothesis of a possible origin of the clays from marine sedimentary deposits which explains the widespread presence of relics of marine foraminifera microfossils in the ceramic paste observed by SEM [26]. It raises questions on the variability of supply of raw materials between the region of origin of this sherd and those produced near the Malpaís of Zacapu.

These results are the first step in understanding the techniques used for pigment preparations and ceramic decorations of the Palacio and Milpillas phases, but also in identifying the origin of the raw materials used in pottery production. Indeed, while iron and titanium oxides are very common in magmatic rocks of volcanic regions such as the lake Zacapu basin, the same cannot be said for bromine, which is found mainly in marine environment, nor for graphite presence. The continuation of the study of the origin of these raw materials is expected to highlight exchanges between the Zacapu area and other regions in Early and Middle Postclassic periods, at the moment still unknown.

\section{Aknowledgements}

We wish to thank Dr. Gregory Pereira for access to the ceramic of the Uacúsecha project and Dr. Maria Filomena Guerra for her feedback on this paper. M. Manso acknowledges the support of the Portuguese Foundation for Science and Technology (FCT) for the grant Ref. SFRH/BPD/ $70031 / 2010$ 


\section{Table 2}

Mineralogical phases detected by $\mu$-Raman spectroscopy and $\mu$-XRD on the samples. Albt: albite; Amorph: amorphous; Ant: anatase; Cal: calcite; Car: carbon; Crn: corundum; Crist: cristobalite; Dis: disordered; Enst: enstatite; Graph: graphite; Hem: hematite; Ilm: ilmenite; Lign: lignite; Mag: magnetite; pyroxene: Pyrx; Qtz: quartz; Rt: rutile; Sil: silica.

\begin{tabular}{|c|c|c|c|}
\hline Samples & Colours & XRD & Raman \\
\hline \multirow[t]{7}{*}{1} & Red & Hem & Hem \\
\hline & & Mag & Ant \\
\hline & & Pyrx & \\
\hline & & Ant & \\
\hline & & Albt & \\
\hline & Greyish-black & Lign & Hem \\
\hline & & & Mag \\
\hline \multirow[t]{5}{*}{$2 a$} & White & Crist & Hem \\
\hline & & & Ant \\
\hline & Greyish-black & Dis Graph & Amorph Car \\
\hline & & Crist & \\
\hline & & Ant & \\
\hline \multirow[t]{6}{*}{ b } & Red & Hem & Hem \\
\hline & & Mag & Mag \\
\hline & & & Qtz \\
\hline & Greyish-black & & Amorph Car \\
\hline & & & Mag \\
\hline & & & Qtz \\
\hline \multirow[t]{3}{*}{3} & Black & Graph & Graph \\
\hline & & Qtz & Amorph Car \\
\hline & & Albt & \\
\hline \multirow[t]{4}{*}{4} & Red & Hem & Hem \\
\hline & & Qtz & \\
\hline & Orange & Qtz & Qtz \\
\hline & & Cal & Ant \\
\hline \multirow[t]{5}{*}{5} & Red & & Hem \\
\hline & & & Mag \\
\hline & & & Rut \\
\hline & Light red & & Hem \\
\hline & White & & Ant \\
\hline \multirow[t]{4}{*}{6} & Black & Dis Graph & Amorph Car \\
\hline & & Albt & \\
\hline & & Qtz & \\
\hline & & Enst & \\
\hline 7 & Black & & Amorph Car \\
\hline \multirow[t]{2}{*}{8} & Black & & Amorph Car \\
\hline & Brown & & \\
\hline \multirow[t]{2}{*}{9} & Red & & Hem \\
\hline & White & & Ant \\
\hline \multirow[t]{6}{*}{10} & Red & & Hem \\
\hline & & & Mag \\
\hline & White & & Sil \\
\hline & Greyish-black & & Hem \\
\hline & & & Mag \\
\hline & & & Amorph Car \\
\hline
\end{tabular}

\section{References}

[1] E. Jadot, Technologie céramique et frontières culturelles, L'exemple des techniques de décors céramiques de deux sites postclassiques du Malpaís de Zacapu (Mexique): Palacio et Malpaís Prieto (In French), Archéo. doct., 9, 2016 (in press).

[2] A.J. Hirshman, A Case Study in the Relationship Between Social Complexity and the Organization of the Ceramic Production From the Lake Pátzcuaro Basin, Michoacán, Mexico(Ph.D. thesis) Michigan State University, 2003.

[3] A.J. Hirshman, J.R. Ferguson, Temper mixture models and assessing ceramic complexity in the emerging Tarascan state, J. Archaeol. Sci. 39 (10) (2012) 3195-3207.

[4] D. Tenorio, M. Jiménez-Reyes, S. Rivero-Torres, F. Monroy-Guzman, E.T. RomeroGuzman, Characterization of archaeological ceramic from Lagartero, Chiapas,
Mexico, by nuclear and conventional techniques, J. Mex. Chem. Soc. 54 (2010) 40-45.

[5] J.L. Jiménez-Pérez, J. Jiménez-Pérez, A. Brancamontes Cruz, A. Cruz-Orea, J Mendoza-Alvarez, Photoacoustic analysis of pigments from archeological ceramics, Int. J. Thermophys. 25 (2) (2004) 503-510.

[6] R.A. Goodall, J. Hall, R. Viel, P.M. Fredericks, A spectroscopic investigation of pigment and ceramic samples from Copan, Honduras, Archaeometry 51 (1) (2009) 95-109.

[7] L.G. Cecil, H. Neff, Postclassic Maya slips and paints and their relationship to sociopolitical groups in El Peten, Guatemala, J. Archaeol. Sci. 33 (10) (2006) 1482-1491.

[8] N. Schiavon, V. Soria, A.M. Arruda, M. Beltrame, J. Mirão, Losanga decorated imitations of italic late republican black gloss tableware from South-Western Iberia: a multi-analytical/microchemical characterization, Microchem. J. 124 (2016) 712-718.

[9] A.O. Shepard, Plumbate, A Mesoamerican Trade Ware, Carnegie Institution of Washington, 1948.

[10] H. Neff, Production and Distribution of Plumbate Pottery: Evidence From a Provenance Study of the Paste and Slip Clay Used in a Famous Mesoamerican Tradeware (2001 Accessed 04.02.16). URL http://www.famsi.org/reports/98061/

[11] H. Neff, Incidents of archaeology in Central America and Yucatán, essays in honor of Edwin M. Shook, Ch. Sources of Raw Material Used in Plumbate Pottery, University Press of America 2002, pp. 217-231.

[12] P. Ballirano, C.D. Vito, L. Medeghini, S. Mignardi, V. Ferrini, P. Matthiae, D. Bersani, P.P. Lottici, A combined use of optical microscopy, x-ray powder diffraction and micro-Raman spectroscopy for the characterization of ancient ceramic from Ebla (Syria), Ceram. Int. 40 (10) (2014) 16409-16419.

[13] L. Medeghini, P.P. Lottici, C. De Vito, S. Mignardi, D. Bersani, Micro-Raman spectroscopy and ancient ceramics: applications and problems, J. Raman Spectrosc. 45 (2014) 1244-1250.

[14] F. Ospitali, T. Sabetta, F. Tullini, M.C. Nannetti, G. Di Lonardo, The role of Raman microspectroscopy in the study of black gloss coatings on Roman pottery, J. Raman Spectrosc. 36 (1) (2005) 18-23.

[15] A. Guilherme, S. Pessanha, M. Carvalho, J. dos Santos, J. Coroado, Micro energy dispersive X-ray fluorescence analysis of polychrome lead-glazed Portuguese faiences, Spectrochim. Acta B At. Spectrosc. 65 (4) (2010) 328-333.

[16] A. Guilherme, M. Manso, S. Pessanha, A. Zegzouti, M. Elaatmani, R. Bendaoud, J. Coroado, J.M.F. dos Santos, M.L. Carvalho, Micro-XRF for characterization of Moroccan glazed ceramics and Portuguese tiles, J. Instrum. 8 (02) (2013) C02055.

[17] J. van der Weerd, G.D. Smith, S. Firth, R.J. Clark, Identification of black pigments on prehistoric southwest American potsherds by infrared and Raman microscopy, J. Archaeol. Sci. 31 (10) (2004) 1429-1437.

[18] I.M. Bell, R.J. Clark, P.J. Gibbs, Raman spectroscopic library of natural and synthetic pigments (pre- 1850 AD), Spectrochim. Acta A Mol. Biomol. Spectrosc. 53 (12) (1997) 2159-2179.

[19] D. Bikiaris, S. Daniilia, S. Sotiropoulou, O. Katsimbiri, E. Pavlidou, A. Moutsatsou, Y Chryssoulakis, Ochre-differentiation through micro-Raman and micro-FTIR spectroscopies: application on wall paintings at Meteora and Mount Athos, Greece, Spectrochim. Acta A Mol. Biomol. Spectrosc. 56 (1) (2000) 3-18.

[20] D.L.A. de Faria, S. Venancio Silva, M.T. de Oliveira, Raman microspectroscopy of some iron oxides and oxyhydroxides, J. Raman Spectrosc. 28 (11) (1997) 873-878.

[21] O.P. Gosselain, Bonfire of the enquiries. Pottery firing temperatures in archaeology: what for? J. Archaeol. Sci. 19 (3) (1992) 243-259.

[22] J. Zuo, C. Xu, C. Wang, Z. Yushi, Identification of the pigment in painted pottery from the Xishan site by Raman microscopy, J. Raman Spectrosc. 30 (12) (1999) 1053-1055.

[23] N. Schiavon, A. Candeias, T. Ferreira, M. da Conceição Lopes, A. Carneiro, T. Calligaro J. Mirão, A combined multi-analytical approach for the study of Roman glass from south-west Iberia: synchrotron $\mu$-XRF, external-PIXE/PIGE and BSEM-EDS, Archaeometry 54 (6) (2012) 974-996.

[24] F. Froment, A. Tournie, P. Colomban, Raman identification of natural red to yellow pigments: ochre and iron-containing ores, J. Raman Spectrosc. 39 (5) (2008) $560-568$.

[25] M. Horn, C.F. Schwerdtfeger, E.P. Meagher, Refinement of the structure of anatase at several temperatures, Z. Krist. (1972) 273-281.

[26] A. Ballio, Chimica della porpora: una sintesi che inizia dal mare e si completa sulla terra, in: O. Longo (Ed.), La porpora: realtá e immaginario di un colore simbolico (In Italian), Atti del convegno di Studiolstituto veneto di scienze, lettere ed arti, Venezia 1998, pp. 41-52. 